\title{
PENGARUH PENDIDIKAN PERKOPERASIAN DAN KOMITMEN ORGANISASI TERHADAP PARTISIPASI ANGGOTA KOPERASI CU PUNDHI ARTA
}

\author{
Rama Trisuladana ${ }^{1}$, Aris Suparman ${ }^{2}$ \\ ${ }^{1}$ Universitas Muhammadiyah Yogyakarta \\ trisuladana@yahoo.com \\ ${ }^{2}$ Universitas Muhammadiyah Yogyakarta
}

\begin{abstract}
Members in cooperative enterprises have multiple roles, as owners and customers or users, so that the sustainability of cooperative business is dependent on the participation of members. Cooperative education and organizational commitment for most cooperatives have not been considered as an important role to increase member participation. This study aims to determine the influence of cooperative education on the participation of members and the influence of organizational commitment to member participation.
\end{abstract}

Sampling technique in this research use accidental sampling technique with questioner. The analysis used is structural equation modeling (SEM). The population is a member of Cooperative CU Pundhi Arta with a total of 109 respondents.

The results showed that cooperative education and organizational commitment had a positive and significant effect on the participation of members in Cooperative CU Pundhi Arta.

Keywords : Cooperative education, organizational commitment and participation of member

CC 2017 JBTI. All rights reserved

Article history : received 16 Feb 2017; revised 18 Mar 2017; accepted 10 Apr 2017

\section{PENDAHULUAN}

Pada Koperasi ada istilah "dari oleh untuk anggota", yang artinya anggota merupakan pemilik, pengelola sekaligus sebagai pengguna barang dan jasa yang dihasilkan oleh koperasi. Sehingga berkembang atau tidaknya sebuah koperasi tergantung oleh kontributif dari anggota atau sering disebut partisipasi anggota. Partisipasi anggota sebagai pemilik diantaranya partisipasi dalam bentuk modal koperasi, penyampaian kritik dan saran serta pengawasan jalannya usaha koperasi.

Partisipasi anggota sebagai pengelola adalah apabila anggota ditunjuk sebagai pengurus dalam menjalankan usaha koperasi. Dan partisipasi sebagai pengguna barang dan jasa yang dihasilkan oleh koperasi dimana anggota sebagai konsumen utama dari produk barang dan jasa yang dihasilkan oleh koperasi.

Karena pentingnya partisipasi anggota bagi perkembangan usaha koperasi, peneliti yang merupakan aparatur sipil negara pembina koperasi di Kabupaten Bantul dan juga merupakan pengurus Dewan Koperasi Nasional Daerah (DEKOPINDA) Kabupaten Bantul (2015 - 2020), mengidentifikasikan beberapa kelemahan yang ada pada koperasi utamanya di Kabupaten Bantul, diantaranya yaitu lemahnya pemahaman tentang perkoperasian pada anggota, lemahnya keterlibatan 
anggota dan lemahnya koperasi dalam meningkatkan komitmen organisasional. Lemahnya pemahaman tentang perkoperasian pada anggota disebabkan oleh kurangnya sosialisasi, pelatihan maupun pendidikan perkoperasian di pendidikan formal maupun non formal. Sistem pendidikan formal di Indonesia dirasa kurang dalam memberikan pemahaman perkoperasian.

Bung Hatta yang dinobatkan sebagai Bapak Koperasi Indonesia pernah berpesan "Bukan koperasi namanya manakala di dalamnya tidak ada pendidikan tentang koperasi". Beliau melihat pentingnya pendidikan perkoperasian dan pemahaman tentang pengelolaan koperasi bagi anggota. Anggota yang tingkat pemahaman perkoperasiannya tinggi akan berusaha untuk memajukan usaha koperasi.

Rendahnya keterlibatan anggota dalam kegiatan koperasi dan kesediaan untuk melakukan usaha-usaha demi perkembangan organisasi menunjukkan lemahnya komitmen organisasi anggota. Peneliti melihat, rendahnya keterlibatan anggota bukan hanya karena saat perekrutan anggota, tetapi juga karena koperasi tersebut kurang melibatkan anggotanya dalam kegiatan-kegiatan yang dilakukan oleh koperasi. Contohnya ada banyak koperasi yang saat penyelenggaraan Rapat Anggota Tahunan (RAT) tidak mengundang seluruh anggota koperasi.

Koperasi CU (credit union) Pundhi Arta yang beralamatkan di Gubug, Argosari, Sedayu, Bantul, Yogyakarta rutin mengadakan pelatihan bagi anggota baru, setiap jumlah anggota baru telah mencapai 40 orang akan diadakan pelatihan perkoperasian, tingkat kehadiran peserta pelatihan sekitar $70 \%$ dari undangan yang dibagikan. Peserta yang tidak mengikuti pelatihan perkoperasian tidak mendapatkan kesempatan pada periode pelatihan perkoperasian yang selanjutnya dan kurang ada upaya dari pengurus untuk meningkatkan pemahaman perkoperasian utamanya yang belum mengikuti pelatihan perkoperasian. Sehingga dipastikan anggota Koperasi CU Pundhi Arta masih banyak yang belum mengikuti pendidikan perkoperasian.

Anggota yang aktif berpartisipasi menabung dan meminjam pada koperasi CU Pundhi Arta masih rendah. Partisipasi anggota dalam RAT juga masih rendah, karena Pengurus tidak mengundang seluruh anggota dalam RAT. Tidak diundangnya seluruh anggota dalam RAT menunjukkan lemahnya usaha pengurus untuk meningkatkan komitmen anggota koperasi.

Penelitian pengaruh pendidikan perkoperasian terhadap partisipasi anggota pernah dilakukan oleh Siti Za'imatun Nisa (2014), yang membedakan dengan penelitian ini adalah tingkat pendidikan dari anggotanya. Siti Za'imatun Nisa (2014) meneliti Koperasi Mahasiswa Universitas Negeri Yogyakarta (KOPMA UNY) yang anggotanya mahasiswa Universitas Negeri Yogyakarta. Sedangkan pada penelitian ini dilaksanakan pada Koperasi CU Pundhi Arta yang anggotanya tidak dibatasi tingkat pendidikannya. Penelitian yang dilakukan Siti Za'imatun Nisa (2014) menunjukkan adanya pengaruh positif dan signifikan pendidikan perkoperasian terhadap partisipasi anggota.

Penelitian lain yang relevan adalah penelitian yang dilakukan oleh Rusyana, Azis Fathoni dan M Mukeri Warso yang dipublikasikan di Jurnal of Management vol. 2 No. 2, Maret 2016 dengan judul "Pengaruh Partisipasi, Komitmen dan Kemampuan Inovasi Anggota Terhadap Arah Pengembangan Koperasi". Hasil penelitian yang dilakukan oleh Rusyana, Azis Fathoni dan M Mukeri Warso menunjukkan bahwa variabel partisipasi anggota, komitmen anggota dan kemampuan inovasi terhadap arah pengembangan koperasi adalah signifikan.

\section{KAJIAN TEORI}

Pada koperasi, kelangsungan hidup organisasi sangat tergantung pada anggota koperasi mengingat prinsip dalam koperasi adalah dari anggota, oleh anggota dan untuk anggota (Harsoyo dkk, 2006). Koperasi adalah milik bersama para anggota dan usahanya ditujukan terutama untuk 
memenuhi kepentingan anggota-anggota itu, maka usaha Koperasi sangat tergantung pada partisipasi para anggotanya. (Revrisond Baswir, 2013).

Partisipasi dimaknai sebagai keikutsertaan anggota dalam kegiatan-kegiatan tertentu, baik dalam kondisi yang menyenangkan maupun dalam kondisi yang tidak menyenangkan (Hendar, 2010). Menurut Jochen Ropke (2003), partisipasi dibutuhkan untuk mengurangi kinerja yang buruk, mencegah penyimpangan dan membuat pemimpin koperasi bertanggung jawab.

Dilihat dari kedudukan anggota dalam koperasi, partisipasi pada koperasi dapat berupa partisipasi kontributif (contribution participation) dan dapat pula partisipasi insentif (incentive participation). Kedua partisipasi ini timbul karena adanya peran ganda anggota sebagai pemilik sekaligus sebagai pelanggan. Dalam kedudukannya sebagai pemilik peran anggota adalah:

1. Para anggota memberikan kontribusinya terhadap pembentukan dan pertumbuhan perusahaan koperasi dalam bentuk kontribusi keuangan (penyerahan simpanan pokok, simpanan wajib, simpanan sukarela), dan

2. Mengambil bagian dalam penetapan tujuan, pembuatan keputusan dan proses pengawasan terhadap jalannya perusahaan koperasi.

Partisipasi semacam ini disebut partisipasi kontributif. Kemudian dalam kedudukannya sebagai pelanggan atau pemakai, para anggota memanfaatkan potensi pelayanan yang disediakan oleh koperasi dalam menunjang kepentingannya. Partisipasi semacam ini disebut partisipasi Insentif (Hendar, 2011).

Menurut Hendar (2010), partisipasi dalam melaksanakan pelayanan yang disediakan koperasi akan berhasil apabila ada kesesuaian antara anggota, program dan manajemen. Kesesuaian antara anggota dan program adalah adanya kesepakatan antara kebutuhan anggota dan keluaran (output) program koperasi. Kesesuaian antara anggota dan manajemen akan terjadi apabila anggota mempunyai kemampuan (kompetensi) dan kemauan dalam mengemukakan hasrat kebutuhannya (permintaan) yang kemudian harus direfleksikan dalam keputusan manajemen. Terakhir harus ada kesesuaian antara program dan manajemen, di mana tugas dari program harus sesuai dengan kemampuan manajemen untuk melaksanakan dan menyelesaikannya.

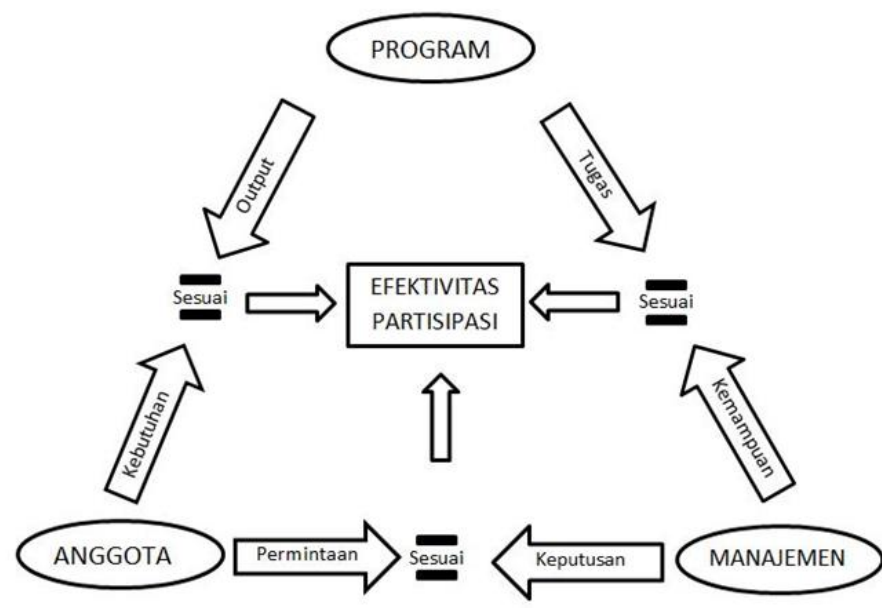

Gambar 1. Model Kesesuaian Partisipasi

Menurut Jochen Ropke (2003), kualitas partisipasi tergantung pada interaksi dari tiga variabel yaitu, anggota atau penerima manfaat, manajemen dan program. Sedangkan menurut Sugiharsono (2010) partisipasi anggota dipengaruhi oleh pemahaman anggota tentang koperasi, kualitas layanan manajemen dan usaha koperasi dan manfaat ekonomi maupun non ekonomi yang 
diperoleh anggota dari koperasi yang bersangkutan. Pemahaman anggota tentang koperasi didapatkan dalam pendidikan perkoperasian.

Kemudian Revrisond Baswir (2010) mengemukakan arti pentingnya pendidikan perkoperasian bagi anggotanya, yakni: "Pengembangan sumberdaya manusia koperasi, dalam kaitannya dengan tantangan yang dihadapi oleh koperasi di masa depan, adalah masalah utama. Karena itu, koperasi harus mampu mengantisipasi pola pendidikan dan latihan sumberdaya manusianya yang paling sesuai dengan kebutuhan pengembangannya".

Pendidikan perkoperasian yang disediakan koperasi untuk anggotanya dapat mempengaruhi pertisipasi anggota. Menurut pendapat Hendar (2010: 174), bagi anggota yang berpendidikan lebih tinggi akan memanfaatkan partisipasi sebagai sarana penyaluran ide dan gagasan, khususnya bagi kepentingan dirinya.

Pendidikan perkoperasian indikator pengukurannya sebagai berikut:

1. Frekuensi keterlibatan anggota dalam pendidikan dan pelatihan perkoperasian;

2. Ketepatan dan kesesuaian materi pendidikan dan pelatihan perkoperasian terhadap kebutuhan anggota;

3. Manfaat yang didapatkan dari program pendidikan dan pelatihan perkoperasian bagi anggota.(Siti Zaimatun Nisa, 2014).

Selain pendidikan perkoperasian, komitmen organisasi juga mempengaruhi partisipasi anggota. Kelangsungan hidup organisasi sangat tergantung pada anggota koperasi mengingat prinsip dalam koperasi adalah dari anggota, oleh anggota, dan untuk anggota. Oleh karena itu, keterlibatan anggota dalam kegiatan-kegiatan koperasi dan komitmen para anggota terhadap koperasi akan sangat berpengaruh terhadap kelangsungan hidup koperasi. (Harsoyo Y., dkk, 2006).

Komitmen organisasional adalah perasaan, sikap dan perilaku individu mengidentifikasikan dirinya sebagai bagian dari organisasi, terlibat dalam proses kegiatan organisasi dan loyal terhadap organisasi dalam mencapai tujuan organisasi (Wibowo, 2014). Komitmen organisasional merupakan kompetensi individu dalam mengikatkan dirinya terhadap nilai dan tujuan organisasi. Keterikatan individu terhadap nilai dan tujuan organisasi akan mendorong individu untuk selalu menyesuaikan atau menyelaraskan dirinya dengan tujuan dan kepentingan organisasi, menjadikan individu memiliki loyalitas yang kuat terhadap organisasi dan menjadikan anggota organisasi tetap tinggal dan bekerja dalam organisasi ini (Sudarmanto, 2015).

Komitmen organisasi indikator pengukurannya sebagai berikut:

1. Identifikasi dengan organisasi, yaitu penerimaan tujuan organisasi (dasar dari komitmen organisasi). Terlihat melalui sikap menyetujui kebijakan organisasi, kesamaan nilai pribadi dan nilai-nilai organsiasi dan rasa kebanggaan menjadi bagian dari organisasi.

2. Keterlibatan sesuai peran dan tanggungjawab di organisasi tersebut. Terlihat melalui sikap menerima dan bertanggungjawab terhadap tugas yang diberikan kepadanya.

3. Keinginan untuk tetap bergabung dengan organisasi untuk jangka waktu lama. (Rusyana, Azis Fathoni dan M Mukeri Warso, 2016).

Berdasarkan uraian diatas dan penelitian terdahulu peneliti melakukan hipotesis sebagai berikut:

H1 : Terdapat pengaruh positif dan signifikan pendidikan perkoperasian terhadap partisipasi anggota Koperasi CU Pundhi Arta, 
$\mathrm{H} 2$ : Terdapat pengaruh positif dan signifikan komitmen organisasional terhadap partisipasi anggota Koperasi CU Pundhi Arta dengan model penelitian sebagai mana gambar 2

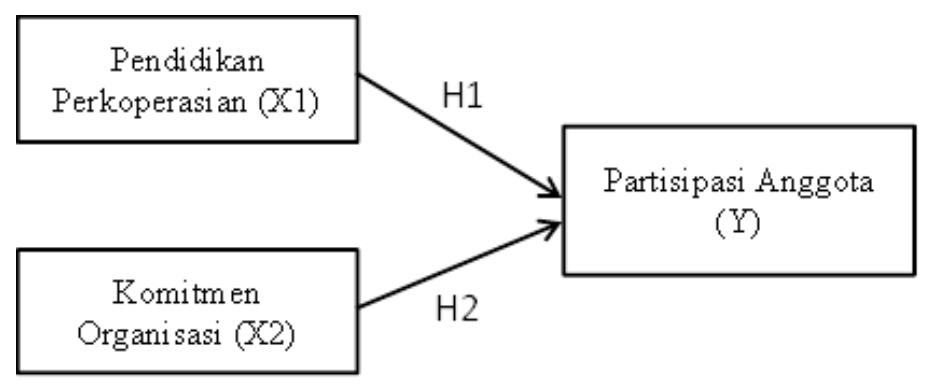

Gambar 2. Model Penelitian

\section{METODE PENELITIAN}

Waktu pelaksanaan penelitian dilakukan pada bulan Februari 2017, sedangkan tempat pelaksanaan penelitian di Kantor Koperasi CU Pundhi Arta, Gubug, Argosari, Sedayu, Bantul. Subyek penelitian adalah anggota Koperasi CU Pundhi Arta yang berjumlah 1455 anggota (laporan RAT TB 2016).

Selanjutnya teknik sampling yang akan digunakan adalah accidental sampling/sampel insidental. Menurut Sugiyono (2014), sampel insidental adalah teknik penentuan sampel berdasarkan kebetulan, yaitu siapa saja yang secara kebetulan bertemu dengan peneliti dapat digunakan sebagai sampel, apabila dipandang orang yang kebetulan ditemui itu cocok sebagai sumber data. Jumlah sampel yang digunakan sebanyak 109.

Pendekatan yang digunakan adalah pendekatan kuantitatif. Pendekatan kuantitatif merupakan penelitian dengan data yang digunakan berupa angka-angka atau data kualitatif yang diangkakan, (Sugiyono, 2014). Jenis data yang akan digunakan adalah data primer yang bersumber langsung dari anggota koperasi. Teknik pengumpulan data dengan metode survai yang dilakukan dengan kuisioner. Kuisioner merupakan teknik pengumpulan data yang dilakukan dengan cara memberi seperangkat pertanyaan atau pernyataan tertulis kepada responden (Sugiyono, 2013). Kuesioner disusun menggunakan Skala Likert dengan lima jawaban bertingkat dari masing-masing pernyataan.

Teknik analisis data yang digunakan adalah Structural Equation Modeling (SEM). SEM digunakan dalam penelitian ini berdasarkan pertimbangan bahwa SEM memiliki kemampuan untuk menggabungkan model pengukuran dan model struktural secara simultan dan mempunyai kemampuan menguji pengaruh langsung dan tidak langsung. SEM sangat cocok digunakan karena dalam penelitian ini menggunakan variabel yang diukur oleh indikator (model pengukuran) dan masing-masing variabel berpengaruh terhadap variabel yang lain (model struktural).

\section{ANALISIS DATA DAN HASIL PENELITIAN}

\section{a. Karakteristik Responden}

Berdasarkan dari isian kuesioner didapatkan karakteristik dari responden menurut usia, jenis kelamin dan pendidikan terakhir. Adapun karekteristik responden dapat dilihat pada tabel berikut: 
Tabel 1.

Karakteristik Responden

\begin{tabular}{|c|c|c|c|c|}
\hline NO & \multicolumn{2}{|c|}{ KARAKTERISTIK } & FREKUENSI & PERSENTASE \\
\hline \multirow[t]{3}{*}{1.} & \multirow[t]{2}{*}{ Jenis Kelamin } & Laki-Laki & 22 & $20,18 \%$ \\
\hline & & Perempuan & 87 & $79,82 \%$ \\
\hline & \multicolumn{2}{|l|}{ Jumlah } & 109 & $100 \%$ \\
\hline \multirow[t]{4}{*}{2.} & \multirow[t]{3}{*}{ Usia } & 20 sd 34 tahun & 15 & $13,76 \%$ \\
\hline & & 35 sd 56 tahun & 53 & $48,62 \%$ \\
\hline & & Diatas 57 tahun & 41 & $37,62 \%$ \\
\hline & \multicolumn{2}{|l|}{ Jumlah } & 109 & $100 \%$ \\
\hline \multirow[t]{6}{*}{3.} & \multirow[t]{5}{*}{ Pendidikan } & SD & 10 & $9,17 \%$ \\
\hline & & SLTP & 5 & $4,59 \%$ \\
\hline & & SLTA & 44 & $40,37 \%$ \\
\hline & & D2/D3 & 4 & $3,67 \%$ \\
\hline & & S1 & 46 & $42,20 \%$ \\
\hline & \multicolumn{2}{|l|}{ Jumlah } & 109 & $100 \%$ \\
\hline
\end{tabular}

\section{b. Uji Validitas}

Uji validitas digunakan untuk mengukur kualitas alat ukur (Tjahjono, 2015). Uji validitas dalam Structural Equation Modeling atau SEM sering disebut analisis faktor konfirmatori. Analisis faktor konfirmatori dapat menguji apakah indikator-indikator yang mengukur variabel merupakan indikator yang valid atau tidak valid. Cara menguji validitas dilakukan dengan uji signifikansi parameter dan standardized estimate. Uji signifikansi parameter dianalisis dengan syarat nilai C.R. $>1,96$, sedangkan standardized estimate dianalisis dengan syarat standardized estimate $>0,5$. Uji validitas dalam penelitian ini dilakukan secara parsial antara variabel eksogen dengan variabel endogen.

Berdasarkan hasil analisa data, 10 butir pernyataan pada analisa faktor konfirmatori variabel eksogen gugur, dan 3 butir pernyataan pada analisas faktor konfirmatori variabel endogen gugur.

\section{c. Uji Reliabilitas}

Uji Reliabilitas dengan Uji Construct Reliability, yaitu menguji keandalan dan konsistensi data. Memenuhi kriteria apabila Contruct Reliability > 0,7. Nilai Construct Reliability diantara 0,6 s/d 0,7 masih dapat diterima dengan validitas konstruk (indikator) dalam model adalah baik. Hasil perhitungan uji reliabilitas menunjukkan keseluruhan nilai construct reliability dapat diterima atau reliabel. 


\section{d. Uji Outliers}

Uji outliers multivariate di dalam analisis Structural Equation Modeling dapat dilihat pada nilai Mahalanobis distance pada tingkat $\mathrm{p}<0,001$. Mahalanobis distance ini dievaluasi dengan menggunakan chi-square pada derajat kebebasan sebesar jumlah indikator yang digunakan dalam penelitian. Derajat kebebasan untuk model pada penelitian ini berjumlah 25. Chi-square $(\chi 2)$ tabel untuk $\mathrm{df}=25$ dan $\mathrm{p}=0,001$ adalah 52,620, Sehingga apabila mahalanobis distance lebih besar dari nilai chi-square tabel $(52,620)$ berarti dikategorikan sebagai multivariate outliers. Hasil text output Amos 19 nilai mahalanobis distance tertinggi adalah 35,322, sehingga tidak ada outliers.

\section{e. Uji Normalitas}

Estimasi dengan Maximum Likelihood (ML) menghendaki variabel observed harus memenuhi asumsi normalitas multivariate. Data yang berdistribusi normal jika nilai critical ratio (c.r.) dari Multivariate pada kurtosis berada di rentang harga mutlak $\pm 2,58$. Hasil uji normalitas nilai critical ratio di rentang harga mutlak $\pm 2,58$ yaitu $-1,668$, sehingga untuk model ini data berdistribusi normal.

\section{f. Uji Hipotesis}

Selanjutnya dilakukan pengujian hipotesis penelitian. Pengujian hipotesis dilakukan dengan menggunakan nilai t-value dengan tingkat signifikansi 0,05. Nilai t-value dalam program AMOS merupakan nilai Critical Ratio (c.r) pada Regression Weight (group number 1 - Default model) dari fit model (full mode)l. Apabila nilai CriticalRatio (c.r) $\geq 1,967$. Atau nilai probabibilitas $(\mathrm{P}) \leq 0,05$ maka Ho ditolak (hipotesis penelitian diterima). Hasil pengolahan oleh AMOS terhadap full model keseluruhan hipotesis penelitian diterima, dapat dilihat pada tabel berikut:

Tabel 2.

Hasil Uji Hipotesis

\begin{tabular}{|l|l|l|c|c|c|c|c|}
\hline \multicolumn{2}{|l|}{} & $\begin{array}{c}\text { Estimat } \\
\mathrm{e}\end{array}$ & S.E. & C.R. & P & Ket \\
\hline $\begin{array}{l}\text { Partisipasi } \\
\text { Anggota }\end{array}$ & $<--$ & $\begin{array}{l}\text { Pendidikan } \\
\text { Perkoperasian }\end{array}$ & 0,575 & 0,097 & 5,938 & $* * *$ & $\begin{array}{c}\mathrm{H} 1 \\
\text { diterima }\end{array}$ \\
\hline $\begin{array}{l}\text { Partisipasi } \\
\text { Anggota }\end{array}$ & $<---$ & $\begin{array}{l}\text { Komitmen } \\
\text { Organisasi }\end{array}$ & 0,361 & 0,104 & 3,481 & $* * *$ & $\begin{array}{c}\mathrm{H} 2 \\
\text { diterima }\end{array}$ \\
\hline
\end{tabular}

\section{g. Evaluasi Terhadap Kriteria Goodness of Fit Model}

Evaluasi terhadap kriteria goodness of fit model menunjukkan 5 (lima) kriteria baik, karena masuk pada nilai yang direkomendasikan dan 3 (tiga) kriteria marginal karena di luar nilai yang direkomendasikan, Selengkapnya pada tabel 3.

Tabel 3.

Evaluasi Kriteria Goodness-of-fit

\begin{tabular}{|c|c|c|c|c|}
\hline No & Kriteria & $\begin{array}{c}\text { Nilai } \\
\text { Rekomendasi }\end{array}$ & Hasil & $\begin{array}{c}\text { Evaluasi } \\
\text { Model }\end{array}$ \\
\hline
\end{tabular}




\begin{tabular}{|c|l|c|c|c|}
\hline 1. & $\begin{array}{l}\text { Chi-square } \\
(\mathrm{df}=268)\end{array}$ & $\leq 314,638$ & 309,593 & Baik \\
\hline 2. & Probability & $\geq 0,05$ & 0,041 & Marginal \\
\hline 3. & CMIN/DF & $\leq 2,00$ & 1,155 & Baik \\
\hline 4. & GFI & $\geq 0,90$ & 0,821 & Marginal \\
\hline 5. & AGFI & $\geq 0,90$ & 0,783 & Marginal \\
\hline 6. & TLI & $\geq 0,95$ & 0,961 & Baik \\
\hline 7. & CFI & $\geq 0,95$ & 0,965 & Baik \\
\hline 8. & RMSEA & $\leq 0,08$ & 0,038 & Baik \\
\hline
\end{tabular}

Selanjutnya gambar 3 menunjukkan full model dari penelitian ini,

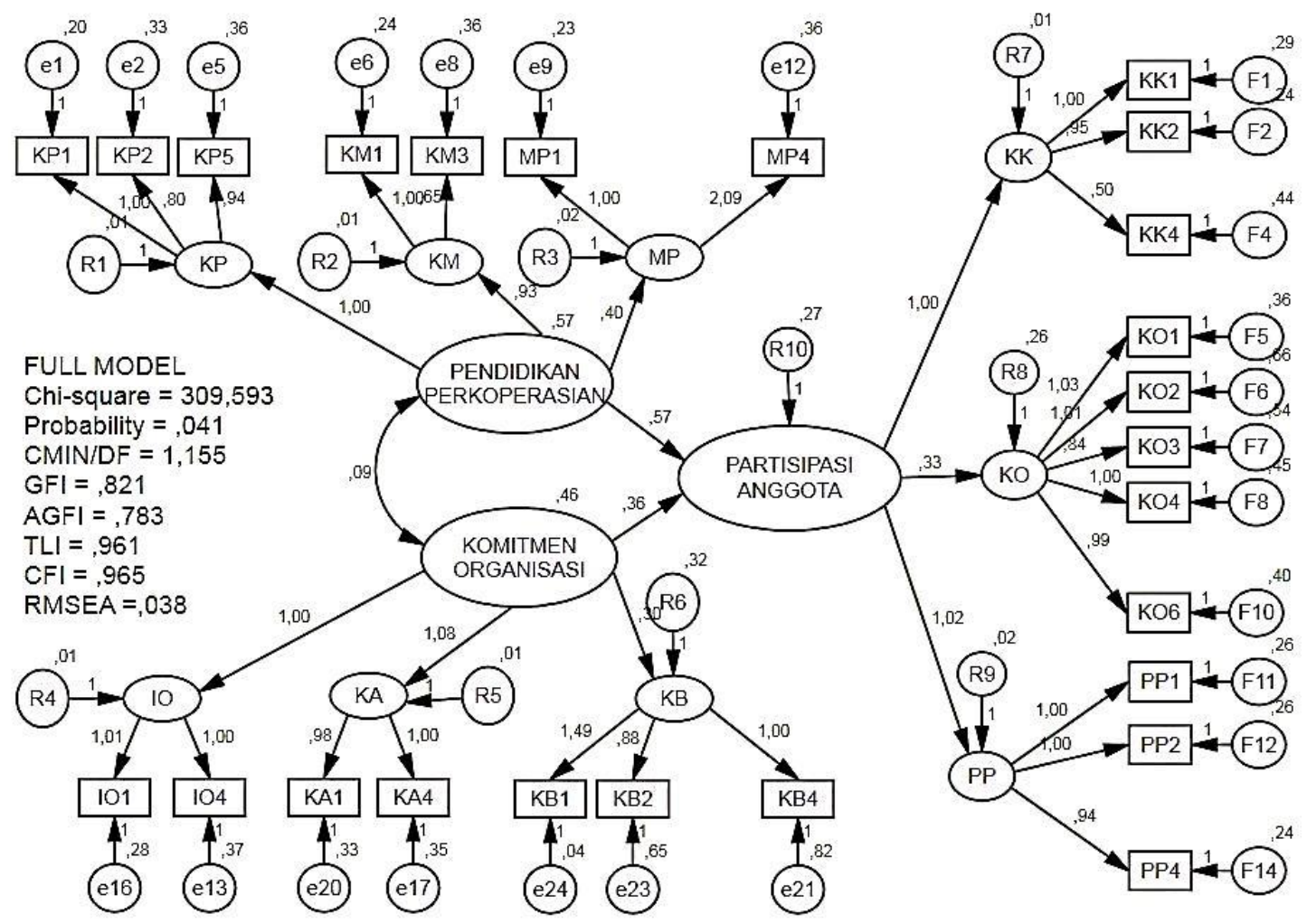

Gambar 3. Full Model

\section{h. Pembahasan}

Hipotesis 1 yang diajukan pada penelitian ini adalah adanya pengaruh positif dan signifikan pendidikan perkoperasian terhadap partisipasi anggota Koperasi CU Pundhi Arta. Penelitian ini berhasil membuktikan bahwa variabel pendidikan perkoperasian berpengaruh positif dan signifikan terhadap partisipasi anggota. Berdasarkan hasil tersebut dapat dijelaskan bahwa meningkatnya 
partisipasi anggota di Koperasi CU Pundhi Arta disebabkan oleh semakin kuatnya pendidikan perkoperasian di Koperasi CU Pundhi Arta. Partisipasi anggota diukur dengan kontribusi keuangan, kontribusi organisasi dan partisipasi pelayanan.

Pendidikan perkoperasian dibutuhkan oleh suatu organisasi koperasi untuk memberikan pemahaman kepada anggota koperasi akan visi, misi dan tujuan organisasi, hak dan kewajiban serta manfaat menjadi anggota koperasi, sekaligus memberikan informasi tentang aturan, tata cara SOP (standar operasional prosedur) dan SOM (standar operasional manajemen) yang dijalankan di organisasi. Pemahaman yang tinggi terhadap organisasinya akan menarik minat mereka untuk lebih berkontributif dan berpartisipasi aktif demi kemajuan organisasi koperasi.

Tinggi rendahnya pendidikan perkoperasian yang mendukung partisipasi anggota Koperasi CU Pundhi Arta telah ditunjukkan oleh indikator yang mengukur pendidikan perkoperasian dalam penelitian ini, yaitu keterlibatan anggota dalam pendidikan dan pelatihan perkoperasian, ketepatan materi dan manfaat dari pendidikan perkoperasian.

Hasil dari penelitian ini mendukung dan memperkuat justifikasi penelitian terdahulu. Hasil penelitian ini sejalan dengan penelitian yang dilakukan oleh Siti Za'imatun Nisa (2015), hasil penelitiannya menunjukkan bahwa terdapat pengaruh positif dan signifikan pendidikan perkoperasian terhadap partisipasi anggota. Hasil penelitian ini juga mendukung penelitian Lailatul dan Riza. (2016), yaitu adanya pengaruh positif dan signifikan pendidikan perkoperasian terhadap partisipasi anggota di Koperasi Mahasiswa.

Selain itu, penelitian ini juga menunjukkan bahwasanya pengaruh positif dan signifikan pendidikan perkoperasian terhadap partisipasi anggota tidak hanya terjadi pada koperasi mahasiswa (KOPMA) tetapi juga koperasi dengan anggota dengan berlatar belakang tingkat pendidikan yang berbeda. Pada penelitian terdahulu, penelitian pengaruh pendidikan perkoperasian terhadap partisipasi anggota dilakukan terhadap koperasi yang beranggotakan mahasiswa, sedangkan pada penelitian ini dilakukan di CU Pundhi Arta yang beranggotakan masyarakat umum dengan latar belakang pendidikan dari sekolah dasar (SD) sampai dengan sarjana (S1), detail latar belakang pendidikan dapat dilihat pada Tabel 1

Hipotesis 2 pada penelitian ini adalah terdapat pengaruh positif dan signifikan komitmen organisasi terhadap partisipasi anggota Koperasi CU Pundhi Arta. Penelitian ini juga berhasil membuktikan variabel komitmen organisasi berpengaruh positif dan signifikan terhadap partisipasi anggota. Berdasarkan hasil tersebut dapat dijelaskan bahwa meningkatnya partisipasi anggota di Koperasi CU Pundhi Arta juga disebabkan oleh meningkatnya komitmen organisasi yang meliputi keterikatan emosional atau identifikasi dengan organisasi, keterlibatan sesuai peran dan tanggungjawab di organisasi dan keinginan untuk tetap bergabung dengan organisasi.

Komitmen organisasi anggota sebagai pemilik sekaligus pengguna dari usaha koperasi ditunjukkan dengan kesediaan untuk mengidentifikasikan dirinya pada koperasi dan kesediaan untuk melakukan usaha-usaha demi perkembangan koperasi akan meningkatkan keinginan anggota untuk membesarkan koperasi dengan cara menjadi anggota aktif (berpartisipasi aktif).

Hasil dari penelitian ini mendukung dan memperkuat justifikasi penelitian terdahulu. Hasil penelitian ini sejalan dengan penelitian yang dilakukan oleh Rusyana, Azis Fathoni dan M Mukeri Warso (2016) yang menyimpulkan bahwa komitmen anggota terhadap pengembangan koperasi adalah signifikan.

Hasil evaluasi terhadap goodness of fit model menunjukan bahwasanya model dari penelitian ini sebagian besar kriteria telah terpenuhi, yaitu chi-square, CMIN/DF, TLI, CFI dan 
RMSEA sedangkan probability, GFI dan AGFI masuk kriteria marginal. Sehingga model penelitian ini telah sesuai dan masuk kriteria goodness of fit model.

\section{KESIMPULAN}

Berdasarkan analisa hasil penelitian ini dapat disimpulkan:

1. Pendidikan perkoperasian berpengaruh positif dan signifikan terhadap partisipasi anggota.

2. Komitmen organisasi berpengaruh positif dan signifikan terhadap partisiapsi anggota.

3. Evaluasi terhadap kriteria goodness of fit model menunjukkan sebagian besar kriteria telah terpenuhi. Goodness of fit model masuk kriteria pada chi-square, CMIN/DF, TLI, CFI dan RMSEA.

4. Variabel pendidikan perkoperasian paling berpengaruh dalam peningkatan partisipasi anggota.

\section{SARAN}

Peneliti merasa penelitian ini masih perlu pengembangan lebih lanjut, berikut saran untuk pengembangan penelitian ini:

1. Pengumpulan data sebaiknya dikombinasikan dengan wawancara sehingga data hasil penelitian akan lebih lengkap.

2. Kemungkinan adanya pengaruh pendidikan perkoperasian terhadap partisipasi anggota yang dimediasi oleh komitmen organisasi.

3. Agar menjaga independensi dalam pengisian kuesioner.

\section{DAFTAR PUSTAKA}

Baswir, R., 2013, Koperasi Indonesia. BPFE Yogyakarta, Yogyakarta.

Harsoyo, Y., dkk, 2006, Ideologi Koperasi Menatap Masa Depan, Pustaka Widyatama, Yogyakarta.

Hendar, 2010, Manajemen Perusahaan Koperasi. Erlangga. Jakarta.

Nisa, S. Z., 2014, Pengaruh Pendidikan Perkoperasian dan Motivasi Anggota Terhadap Partisipasi Anggota Koperasi Mahasiswa Universitas Negeri Yogyakarta (KOPMA UNY). Prodi Pendidikan Ekonomi Fakultas Ekonomi, Universitas Negeri Yogyakarta.

Ropke, J., 2003, Ekonomi Koperasi (Teori dan Manajemen). Diterjemahkan oleh Sri Djatnika, S.E., M.Si. Salemba Empat, Jakarta.

Rusyana, A. F., dan M Mukeri, W., 2016, Pengaruh Partisipasi, Komitmen dan Kemampuan Inovasi Anggota Terhadap Arah Pengembangan Koperasi, Journal of Management Vol. 2 No.2 Maret.

Sudarmanto, 2015, Kinerja dan Pengembangan Kompetensi SDM, Pustaka Pelajar, Yogyakarta..

Sugiharsono, 2010, Pentingnya Partisipasi Anggota Dalam Mendukung Keberhasilan Usaha Koperasi. Jurnal Informasi Vol. 1 XXXVI.

Sugiyono, 2013, Metode Penelitian Pendidikan, Alfabeta, Bandung. 
Sugiyono, 2014, Statistika Untuk Penelitian, Alfabeta, Bandung.

Tjahjono, H.K., 2015, Metode Penelitian Bisnis. VSM MM UMY

Undang-Undang No. 25 Tahun 1992 tentang Perkoperasian

Wibowo, 2014, Manajemen Kinerja. P T. Rajagrafindo Persada, Jakarta. 